\title{
The evaluation of the two-stage prothrombin assay
}

Citation for published version (APA):

Hemker, H. C., Hemker, P. W., v.d. Torren, K., Devilee, P. P., Hermens, W. T., \& Loeliger, E. A. (1971). The evaluation of the two-stage prothrombin assay. Thrombosis et diathesis haemorrhagica, 25(3), 545554. https://doi.org/10.1055/S-0038-1654328

Document status and date:

Published: 01/01/1971

DOI:

10.1055/S-0038-1654328

Document Version:

Other version

\section{Please check the document version of this publication:}

- A submitted manuscript is the version of the article upon submission and before peer-review. There can be important differences between the submitted version and the official published version of record.

People interested in the research are advised to contact the author for the final version of the publication, or visit the DOI to the publisher's website.

- The final author version and the galley proof are versions of the publication after peer review.

- The final published version features the final layout of the paper including the volume, issue and page numbers.

Link to publication

\footnotetext{
General rights rights.

- You may freely distribute the URL identifying the publication in the public portal. please follow below link for the End User Agreement:

www.umlib.nl/taverne-license

Take down policy

If you believe that this document breaches copyright please contact us at:

repository@maastrichtuniversity.nl

providing details and we will investigate your claim.
}

Copyright and moral rights for the publications made accessible in the public portal are retained by the authors and/or other copyright owners and it is a condition of accessing publications that users recognise and abide by the legal requirements associated with these

- Users may download and print one copy of any publication from the public portal for the purpose of private study or research.

- You may not further distribute the material or use it for any profit-making activity or commercial gain

If the publication is distributed under the terms of Article $25 \mathrm{fa}$ of the Dutch Copyright Act, indicated by the "Taverne" license above, 


\section{THROMBOSIS ET DIATHESIS HAEMORRHAGICA}

EDITORES: K. M. BRINKHOUS, CHAPEL HILL; E. DEUTSCH, WIEN; R. GROSS, KÖLN; J. E. JORPES, STOCKHOLM; F. KOLLER, BASEL; J. ROSKAM, LI ÈGE; SOL SHERRY, PHILADELPHIA; J.-P. SOULIER, PARIS; I. S. WRIGHT, NEW YORK

\section{The Evaluation of the Two-Stage Prothrombin Assay}

From the Laboratories for Coagulation Biochemistry and Cardiovascular Biochemical Research, Departments of Haematology and Cardiology, University Hospital, Leiden, The Netherlands

H. C. Hemker, P. W. Hemker, K. v. D. Torren, P. P. Devilee, W. Th. Hermens, E. A. Loeliger

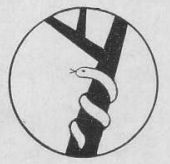

F. K. SCHATTAUER VERLAG - STUTTGART-NEW YORK 
To estimate prothrombin, two kinds of assay are in current use: the one-stage and the two-stage assay. It has been shown that the one-stage assay measures the initial reaction velocity of the prothrombin conversion (Hemker and Muller, 1968). This reaction velocity expresses itself in a clotting time and therefore escapes (bio-)chemical standardization. One has to make do with comparative estimations in which the prothrombin content is expressed as a percentage of a standard normal plasma.

In the two-stage assay the prothrombin from the sample is converted into thrombin, after which this thrombin is measured. Since thrombin is a well-defined serine-esterase whose concentration can be standardized, the two-stage procedure must be considered to be preferable. Moreover, there is evidence that the two-stage assay does not measure the same reactant as the one-stage assay does.

Although in dilutions of normal plasma and in parenchymatous liver disease both tests run fairly parallel, in oral anticoagulant treatment and in vitamin $\mathrm{K}$ deficiency, the two-stage assay gives results that are up to $20 \%$ higher than those obtained with the one-stage assay (Hemker, Muller and Loeliger, 1970). Since prothrombin is defined as the zymogen (or zymogens) giving rise to thrombin (or thrombins), this discrepancy should not pass without notice. In our attempts to study it further, we encountered the difficulty that no satisfactory way of evaluating the results of a two-stage assay exists. The problem resides in the fact that the amount of active thrombin present at any moment in a coagulation mixture is the result of the thrombin-generating and the thrombin-removing processes. But what one is interested in, is the amount of thrombin that would eventually develop if no thrombin-removing processes were going on. This quantity is usually calculated from the experimental data in either of two ways:

1. the English method, which measures the area under the thrombin generation curve (Biggs and Macfarlane, 1967);

2. the American method, which measures the maximal amount of thrombin observed in the coagulation mixture (Wagner et al., 1965).

Both methods are recognized by the authors to give significant results only when the experimental conditions are rigorously standardized. It is the purpose of this communication to propose a way of evaluation of the two-stage assay that gives a figure for the potential thrombin yield that is minimally influenced by the prevailing experimental conditions (concentration of antithrombin, prothrombin etc.).

\section{Materials and Methods}

Normal plasma is a pooled normal plasma obtained from 30 healthy donors, mean age 30 years. 9 parts of blood are collected in 1 part of tri Na-citrate 2 aq., so as to obtain a final concentration of $0.8 \%(w / v)$.

Thromboplastin is human brain thromboplastin prepared according to Owren and Aas (1961).

Thrombos. Diathes. haemorrh. (Stuttg.) 


\section{Euglobulin Preparation}

A $5 \mathrm{ml}$ aliquot of normal plasma was diluted 1:8 with twice-distilled water. The $\mathrm{pH}$ was brought to 5.4 with $1 \%$ acetic acid. The sediment was obtained by centrifugation (10 min, $12,000 \mathrm{~g}, 4^{\circ} \mathrm{C}$ ) and dissolved in $2.5 \mathrm{ml}$ Michaëlisbuffer ( $\mathrm{pH} 7.4$ ). The prothrombin content was $175 \%$ (of the normal plasma) [one-stage estimation according to Loeliger (1952)]. The antithrombin III concentration was less than $1 \%$ (estimated according to Hensen and Loeliger, 1963).

\section{Thrombin Preparation}

A $2.5 \mathrm{ml}$ aliquot of the euglobulin preparation was incubated at $37^{\circ} \mathrm{C}$ with $0.5 \mathrm{ml} \mathrm{CaCl}$ solution $(33 \mathrm{mM})$ and $0.5 \mathrm{ml}$ thromboplastin, diluted $1: 10$, until no further rise in thrombin concentration was observed. This preparation still contains many impurities, notably coagulation factors. These do not play a role, however, under the conditions in which the thrombin reference curve was determined.

The two-stage assay was carried out as follows. A $0.5 \mathrm{ml}$ aliquot of the sample was diluted 1:5 with $2 \mathrm{ml}$ Michaëlisbuffer ( $\mathrm{pH} 7.4$ ), to which Na-citrate was added to a final concentration of $0.8 \%$ $(\mathrm{w} / \mathrm{v})$. One $\mathrm{ml}$ of this mixture was added to $1 \mathrm{ml}$ human brain thromboplastin diluted 1:10 with Michaëlisbuffer ( $\mathrm{pH} 7.4$ ) and $1 \mathrm{ml} \mathrm{CaCl}{ }_{2}$-solution ( $33 \mathrm{mM}_{>}$. This mixture was incubated at $20^{\circ} \mathrm{C}$ or $37^{\circ} \mathrm{C}$. At one-minute intervals, $0,1 \mathrm{ml}$ was subsampled into $0.1 \mathrm{ml} \mathrm{BaSO}_{4}$-adsorbed oxalated bovine plasma diluted $1: 5$, and the coagulation time was recorded.

The thrombin reference curve was prepared by making serial dilutions of the thrombin preparation $\left({ }^{1} / 2,1 / 4,1 / 6\right.$ etc. down to $\left.{ }^{1} / 32\right)$, and estimating the clotting time of $0.1 \mathrm{ml}$ of this dilution with $0.1 \mathrm{ml}$ of $\mathrm{BaSO}_{4}$-adsorbed oxalated bovine plasma diluted $1: 5$. With the aid of this curve, thrombin times obtained in the two-stage assay were converted into arbitrary units (A.U.) of thrombin. The curve of thrombin concentration, plotted against incubation time, is called the thrombin generation curve.

\section{Theoretical Considerations}

The thrombin present in the reaction mixture of a two-stage assay is the result of two competing reactions: the thrombin formation and the thrombin inactivation.

The thrombin formation is a further undefined function of time. Let $Q(t)$ represent the amount of thrombin that has been generated at time $t$, although it may have been inactivated subsequently. From the experiment we want to obtain $Q\left(t_{e}\right)$, i.e. the amount of thrombin that would eventually develop at the end of the experiment, if all the prothrombin were converted into thrombin and no inactivation occurred. The velocity of thrombin generation, not considering the breakdown, is given by the first derivative of $\mathrm{Q}$, i.e. $\mathrm{Q}^{\prime}$.

Thrombin is removed from the incubation mixture according to the reaction: thrombin + antithrombin III $\rightarrow$ metathrombin. It has been shown (Hensen and Loeliger, 1963) and it will also follow from the experimental part of this paper, that a) this reaction ean be considered to be the only significant thrombin-removing reaction under the circumstances of the test, and b) that in this reaction the law of mass action holds, and that antithrombin III is present in sufficient amounts to make the reaction a pseudo-unimolecular one, so that the breakdown velocity at time $t$ is given by

$$
\mathrm{b}(\mathrm{t})=\mathrm{k} \cdot \mathrm{A} \cdot \mathrm{T}(\mathrm{t})
$$

where $\mathrm{A}$ is the antithrombin III concentration and $\mathrm{T}(\mathrm{t})$ is the actual thrombin concentration at time $t$. It follows that the change in concentration of active thrombin $(\mathrm{T})$ at time $t$ is given by the rate of accumulation of total thrombin minus the rate of its degradation

$$
\frac{d T}{d t}=Q^{\prime}(t)-k \cdot A \cdot T(t)
$$


The American way of evaluating a two-stage assay consists of measuring the amount of active thrombin (T) at the moment (say s) that this amount reaches its maximum value. By definition at this moment $\mathrm{s}$ there is no change in the concentration of active thrombin:

$$
\frac{d T}{d t}=0, \text { so that } Q^{\prime}(s)=k \cdot A \cdot T(s) \text { and } T(s)=\frac{Q^{\prime}(s)}{k \cdot A}
$$

From formula (3) it is obvious that the maximal amount of thrombin found [ $T$ (s)] is inversely proportional to the concentration of antithrombin III present, and therefore cannot be a reasonable measure of $\mathbf{Q}\left(t_{e}\right)$, because this quantity has to be proportional to the prothrombin content only.

Rearrangement of formula (2) gives

$$
T(t)=\frac{1}{k \cdot A}\left[Q^{\prime}(t)-\frac{d T}{d t}\right]
$$

What is estimated by measuring the surface $(\mathrm{S})$ under the thrombin generation curve is (by definition)

so

$$
\begin{gathered}
S=\int_{0}^{t_{e}} T d t\left(t_{e}=\right.\text { time at the end of the experiment) } \\
S=\int_{0}^{t_{e}} \frac{1}{k \cdot A \cdot}\left[Q^{\prime}(t)-\frac{d T}{d t}\right] d t \\
S=\frac{1}{k \cdot A \cdot{ }_{0}} \int^{t_{e}} Q^{\prime}(t) d t-\frac{1}{k \cdot A \cdot{ }_{0}} \int^{t_{e}} \frac{d T}{d t} d t
\end{gathered}
$$

by definition

and

$$
\begin{aligned}
& \int_{0}^{t_{e}} Q^{\prime}(t) d t=Q\left(t_{e}\right)-Q(0) \\
& \int_{0}^{t_{e}} \frac{d T}{d t} d t=T\left(t_{e}\right)-T(0)
\end{aligned}
$$

$\mathrm{T}(0)=\mathrm{Q}(0)$ is the amount of thrombin present at zero time and $\mathrm{T}\left(\mathrm{t}_{\mathrm{e}}\right)$ is the amount actually present at the end of the experiment. Both these values are zero, so formula (5) and therefore the last term of formula (4) equal zero; thus

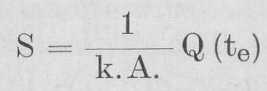

It is evident that the surface $\mathrm{S}$ is proportional to $\mathrm{Q}\left(\mathrm{t}_{\mathrm{e}}\right)$ and therefore to the prothrombin content of the sample, but that is also is inversely proportional to A, i.e. to the antithrombin III content of the sample. S is therefore not a useful quantity to reflect $Q\left(t_{e}\right)$. In all dilutions of a given sample $S$ will have to be equal, because the proportion of $\mathrm{Q}\left(\mathrm{t}_{\mathrm{e}}\right)$ to $\mathrm{A}$ is fixed. In the experimental section this will indeed be shown to be the case.

It is generally known that the generation of thrombin is a relatively quick process. This must mean that for all practical purposes $\mathrm{Q}\left(t_{\mathrm{e}}\right)$ is reached long before the end of the experiment. From that moment on, the thrombin generation curve reflects only the decay process. If this is an adequate approximation, and if the description of the decay process by the action of antithrombin III only is also a fair enough representation of reality, we should get a good impression of the decay process from the last (declining) part of the thrombin generation curve. This would enable us to estimate $\mathrm{Q}\left(\mathrm{t}_{\mathrm{e}}\right)$ according to the following reasoning: 
If the last part of the reaction follows a pseudo-unimolecular course, it must show a straight-line relationship on a plot of $\log T$ versus incubation time ( $t)$, because when $\mathrm{b}(\mathrm{t})=\mathrm{k} \cdot \mathrm{A} \cdot \mathrm{T}_{\mathrm{t}}$ it follows that $\ln \mathrm{T}=\ln \mathrm{To}-\mathrm{k}$. A.t. In that case, linear extrapolation to $t=0$ would approximate the theoretically maximal amount of thrombin with which the decay started, i.e. the amount that would have been present if no decay process had been going on.

It must be stated explicitely that this procedure only approximates $Q\left(t_{e}\right)$. It would be theoretically correct only when all thrombin was indeed generated at zero time. Under actual circumstances it can be foretold to underestimate the real $Q\left(t_{\ominus}\right)$ because the prothrombin not yet converted to thrombin during the first moments of the reaction is immune to the action of antithrombin III. The more the time needed for generation of thrombin is short compared to the time in which a semilogarithmic decay is operative, the less the importance of this complication will be. The complication can be overcome. From the linear part of the downslope of the plot of T versus t; k. A. can be estimated. As shown above [formula (6)] the surface (S) under a curve of $T$ against $t$ equals $Q\left(t_{e}\right) / k$. A. An exact estimate of $Q\left(t_{e}\right)$ is therefore given by S.k. A. This approach involves multiplication of experimental data, and therefore increases the error. Moreover, it would be a tedious procedure. We therefore prefer to investigate the practical usefulness of the quick approximation obtained by logarithmic extrapolation.

The points to be tested experimentally are:

a) the decay part of a thrombin generation curve is a straight line when $\log \mathrm{T}$ is plotted against incubation time;

b) the time lapse during which semi-logarithmic decay is observed is long compared to the phase of thrombin generation;

c) the reaction constant of decay is proportional to the amount of antithrombin III present;

d) extrapolation of the $\log T$ versus $t$-plot to $t=0$ approximates $Q\left(t_{e}\right)$; the value thus obtained therefore approximates the concentration of thrombin that would have been obtained if no antithrombin III had been present, or in other words, the equivalent of the original prothrombin content of the sample.

\section{Experimental Results}

Fig. 1 represents specemina of the conventional thrombin generation curves that were used as an experimental basis. Table 1 shows that in a series of dilutions of the same normal plasma the surface under the curve is indeed constant within the limits of the experimental error. For the surfaces obtained with low plasma dilutions, a tendency to decrease is often observed.

This is readily explained by the fact that below a certain limit thrombin concentrations are often neglected. The area thus discarded with a low-rising but long-lasting curve as obtained with low plasma concentrations is therefore appreciably greater than the area neglected of step-rising and rapidly descending curves. It may be mentioned here in passing that to estimate surfaces under this kind of curves it is not necessary to proceed through the laborious methods of paper-weighing, square-counting or planimetering. It can be easily proven that it is sufficient to add all the thrombin concentrations obtained, provided the sampling times are regularly spaced.

In contrast to the surface areas, the heights of the peaks do, as would be expected, show a certain correlation with the amount of prothrombin originally present. They are not, however, a fair representation of this amount. Moreover, estimation of peak height means the selection of one thrombin estimation from the whole series as the 


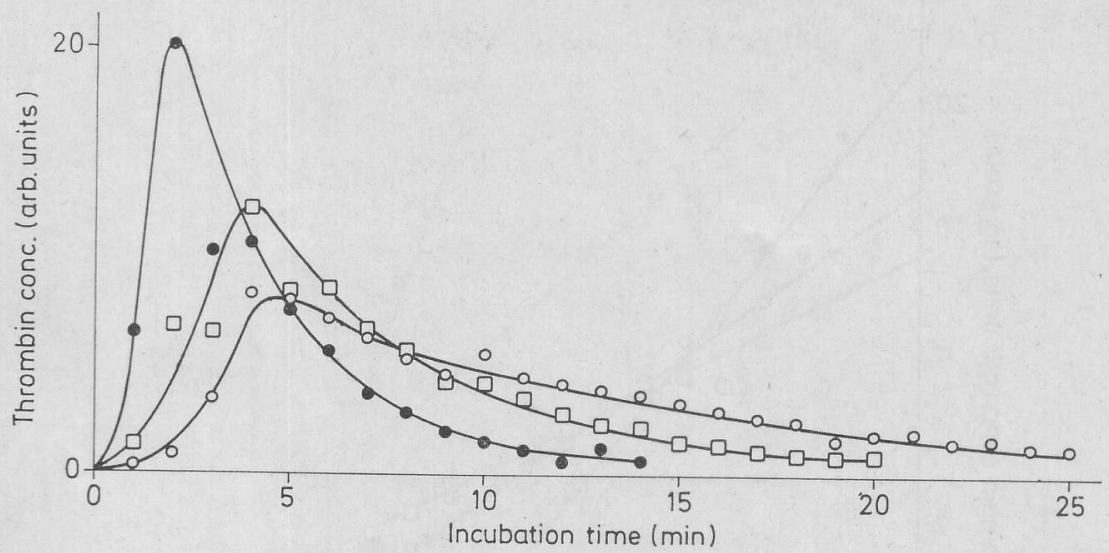

Fig. 1. Thrombin generation curves plotted in a normal graph. (Experiments carried out at $37^{\circ} \mathrm{C}$.) - Undiluted normal plasma sample. $\square 1: 2$ dilution. $\bigcirc 1: 3$ dilution.

Table 1. Surface area and maximal height of thrombin generation curves obtained with dilutions of normal plasma.

\begin{tabular}{c|c|c|c}
\hline Dilution & $\begin{array}{c}\text { Surface area } \\
(\%)\end{array}$ & $\begin{array}{c}\text { Peak height } \\
(\%)\end{array}$ & Expected value \\
\hline $1: 1$ & 100 & 100 & 100 \\
$2: 3$ & 109 & 83 & 66 \\
$1: 2$ & 112 & 62 & 50 \\
$1: 3$ & 92 & 49 & 33 \\
$1: 4$ & 98 & 46 & 25 \\
\hline
\end{tabular}

The surface areas as well as the peak heights are expressed as a percentage of those obtained with an undiluted sample.

representative value, the other data being discarded. This procedure tends to greatly enhance the experimental error, the more so because the thrombin generation curve has to be measured discontinuously, so that the experimentally determined peak height can have any value reached by the curve in the period between one minute before and one minute after the real top has been attained.

Fig. 2 shows the data from Fig. 1 plotted on a semi-logarithmic graph. There seems to be no reason to consider the great majority of the points along the descending slope to deviate from a straight line in this kind of graph. This is again shown by Fig. 3 , representing experiments carried out at $20^{\circ} \mathrm{C}$, whereas those shown in Fig. 2 were done at $37^{\circ} \mathrm{C}$. It is clear from Fig. 4 that at both temperatures used the apparent unimolecular reaction constant of decay [k. A. in formula (2)] is proportional to the antithrombin III concentration present (A) and therefore to the plasma dilution used.

Fig. 5 shows that the virtual thrombin yield at zero time obtained by linear extrapolation to the $y$-axis in a semi-logarithmic graph is almost perfectly proportional to the dilution of the sample at both temperatures tested. The value obtained with the undiluted sample was arbitrarily said to contain 100 units. Conversion into N.I.H.units is easily done when the thrombin reference curve can be made with a standard preparation of thrombin, but no such preparation was available, however. 


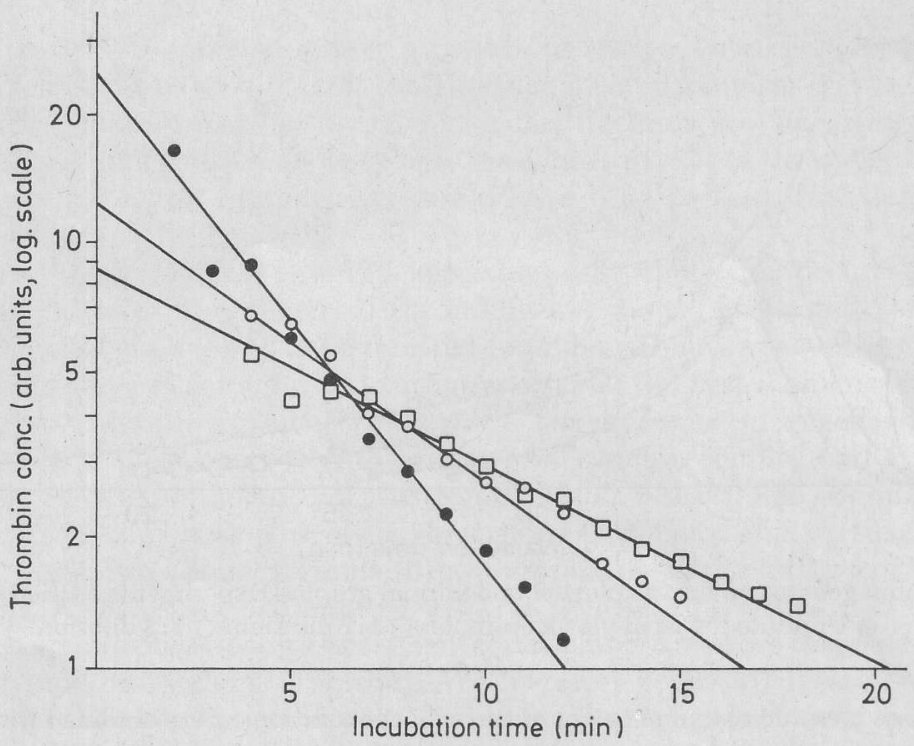

Fig. 2. The thrombin generation curve of Fig.1, plotted in a semi-logarithmic graph. Undiluted normal plasma sample. $\bigcirc 1: 2$ dilution. $\square 1: 3$ dilution.

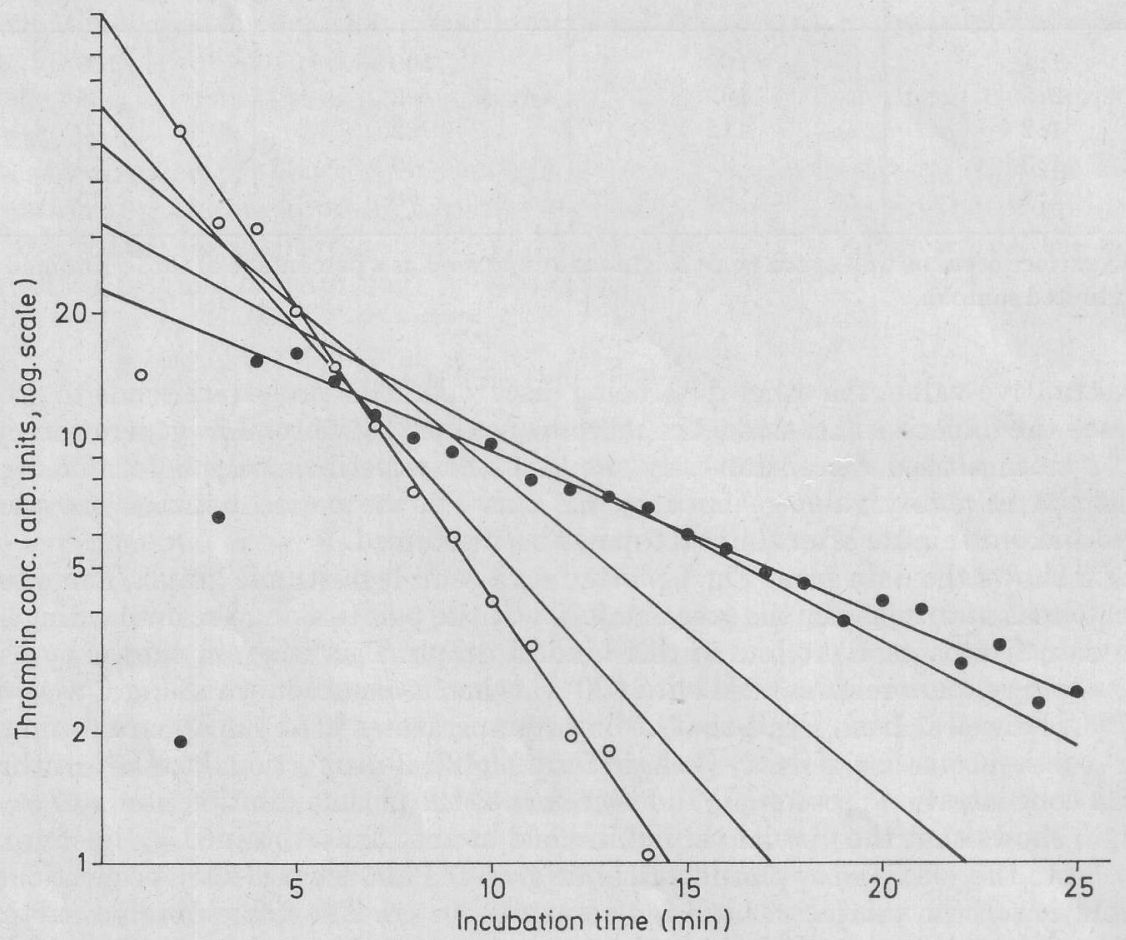

Fig. 3. Thrombin generation eurves in a semi-logarithmic graph. (Experiments carried out at $20^{\circ} \mathrm{C}$.) For the sake of clarity, the experimental points are shown only for the undiluted and the $1: 4$ diluted sample. The drawn lines in between represent $2: 3,1: 2$, and $1: 3$ dilutions resp. 


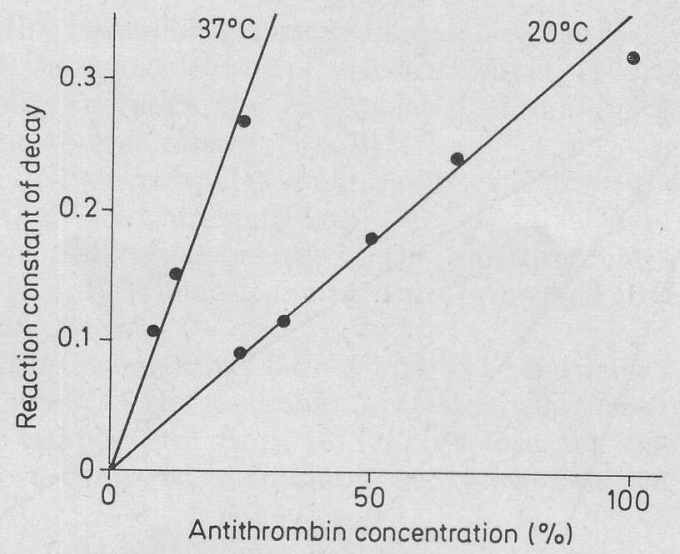

Fig. 4. Reaction constant of decay as a function of plasma concentration. (Data obtained from the experiments shown in Figs. 2 and 3.)

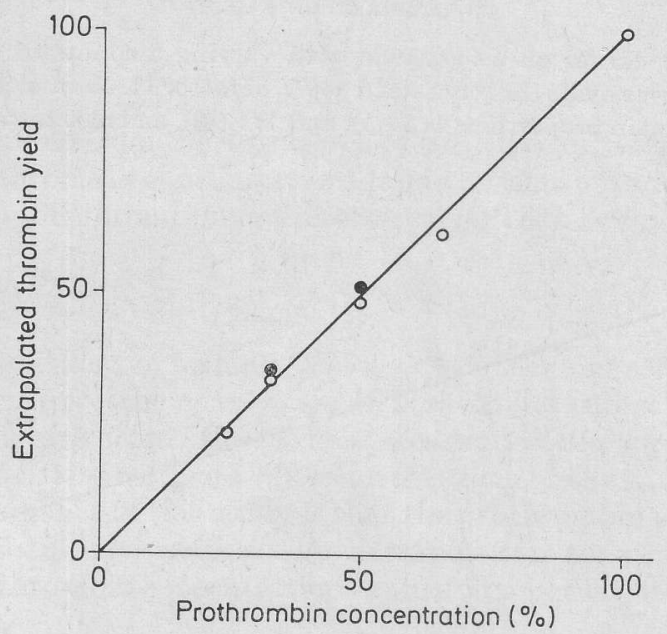

Fig. 5. Extrapolated thrombin yield as a function of plasma concentration. Data from Fig. 2 (black dots; $37^{\circ} \mathrm{C}$ ) and Fig. 3 (open cireles; $20^{\circ} \mathrm{C}$ ). The value obtained with the undiluted plasma is situated at point 100 (by definition). This point is therefore common to both sets of data.

Fig. 6 shows that variation of the antithrombin content causes a proportional variation of the descending slope of the logarithmic graph, but does not alter the extrapolated thrombin yield. The temperature dependency of the decay is shown in Fig. 7. From this Arrhenius graph an experimental activation energy of $\sim 7$ Kcal per mole can be estimated for the decay reaction; $\mathrm{Q}_{10}$ is about 1.5.

\section{Discussion}

From the values in Table 1 it is easily seen that both usual ways of evaluating a thrombin generation curve are very inexact, and from the theoretical considerations it 


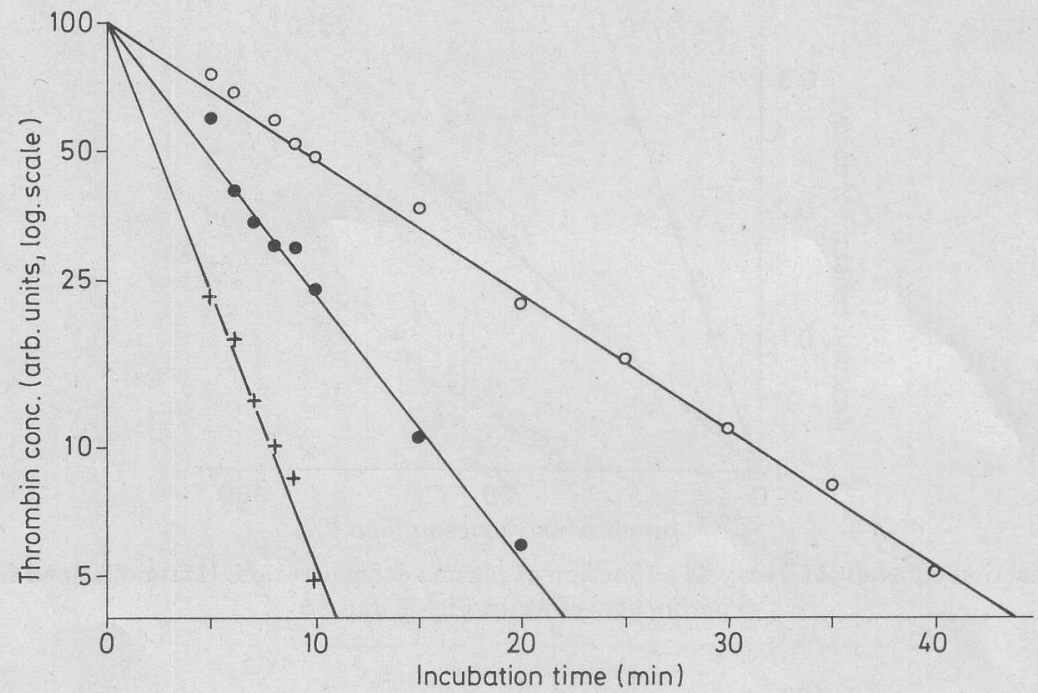

Fig.6. Thrombin decay curves on a log. scale with varying amounts of antithrombin III. An euglobulin preparation was made that contained $100 \%$ of factor II. Normal plasma was mixed with this preparation in proportions $1: 3(0)$, and $1: 1(0)$, and also tested alone $(+)$.

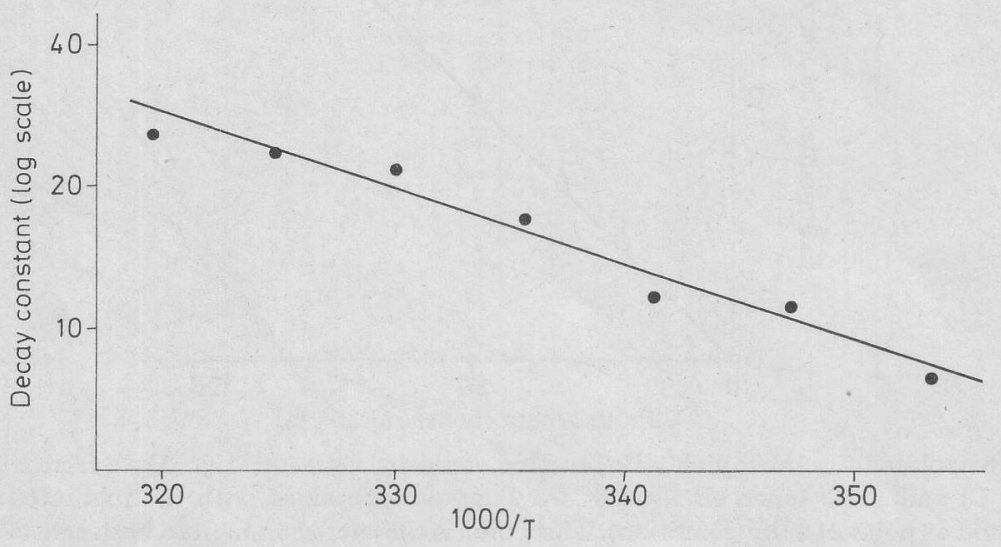

Fig. 7. Arrhenius plot of the decay reaction.

can be seen why this is so. The model on which the theoretical considerations are based considers the thrombin generation curve to be the result of:

first: a relatively short thrombin forming reaction, the exact form (i.e. mathematical description) of which need not to be known for the further development;

and second: a pseudo-monomolecular breakdown of the thrombin present by antithrombin III.

The viability of this model is supported by the finding of:

a) rectilinearity in the descending portion of the thrombin generation curve, when plotted on a semi-logarithmic scale (Figs. 2 and 3); 
b) a proportionality between the pseudo-monomolecular reaction constant and the plasma dilution, i. e. the concentration of antithrombin III (Fig.4);

c) a proportionality between the extrapolated thrombin yield and the plasma dilution, i.e. the prothrombin content (Fig.5);

d) independence of the extrapolated thrombin yield from the slope of the curve, i. e. from the amount of antithrombin (Fig.6).

The relatively low activation energy of the antithrombin - thrombin reaction results in a low $\mathrm{Q}_{10}(\sim 1.5)$. When the temperature is lowered $10^{\circ} \mathrm{C}$, the decay reaction will slow down about 1.5 times.

$\mathrm{Q}_{10}$ of the activation reaction has been found to be between 2.0 and 3.0 (Hemker, 1970 ), the reaction speed of the thrombin formation will therefore slow down about 2.5 times, when the temperature drops $10^{\circ} \mathrm{C}$. Therefore, the assumption that thrombin formation is short compared to thrombin decay will hold better at higher temperatures.

It is interesting to note that from a conventional thrombin generation curve the thrombin formation curve is the strict sense (i.e. without the influence of antithrombin III) can be derived.

From formula (2) it follows that:

$$
Q^{\prime} t=\frac{d T}{d t}+k \cdot A \cdot T
$$

k.A. can be estimated from the downslope of the curve on a logarithmic plot. When $T^{\prime}$ and $T^{\prime \prime}$ are two thrombin concentrations found at time $t^{\prime}$ and $t^{\prime \prime}$ respectively, then the velocity of thrombin formation in this interval ( $\left.Q^{\prime}\right)$ can be found by

$$
\mathrm{Q}^{\prime}=\frac{\mathrm{T}^{\prime \prime}-\mathrm{T}^{\prime}}{\mathrm{t}^{\prime \prime}-\mathrm{t}^{\prime}}+\mathrm{k} \cdot \mathrm{A} \cdot \frac{\mathrm{T}^{\prime \prime}+\mathrm{T}^{\prime}}{2}
$$

This being the equivalent of formula (7) for a discontinuous series of measurements.

Supportive evidence for the correctness of both model and calculation is provided by the fact that, as predicted, the surface area under the curve remains constant within the experimental error, with different dilutions of the same plasma (Table 1). The practical consequence of this study is that the prothrombin concentrations in two stage procedures should be assessed by extrapolation to zero time of the semilogarithmic plot of thrombin concentration against incubation time.

\section{Summary}

It is shown that (and why) the traditional ways of evaluating a thrombin generation curve do not give acceptable estimations of the prothrombin content of the sample. An alternative method is shown to meet the requirements better; it consists of drawing the thrombin generation curve on a semi-logarithmic graph, and extrapolating the descending slope to zero time. This gives a thrombin concentration representing the prothrombin concentration of the original sample.

\section{Résumé}

Il est démontré que les méthodes traditionnelles d'évaluation de la formation de la thrombine ne donnent pas une estimation acceptable de la concentration de la prothrombine dans le matériel étudié. On indique également la raison de ce fait. Une autre méthode est décrite, elle donne des résultats plus valables. Elle consiste à faire 
un graphique semilogarithmique de la courbe de la formation de la thrombine et extrapolel au temps zéro la partie descendante de la courbe. Cela donne une concentration en thrombine représentant la concentration de la prothrombine dans le matériel original.

\section{Zusammenfassung}

Es wird gezeigt, daß (und warum) die übliche Auswertung der Thrombinbildungskurven keine akzeptable Bestimmung des Prothrombingehaltes der Probe gestattet. Es wird gezeigt, daß eine andere Methode den Erfordernissen besser gerecht wird. Sie besteht darin, daß die Thrombinbildungskurve in einem halblogarithmischen System gezeichnet und der Abfall auf die Zeit Null extrapoliert wird. Dies ergibt die Thrombinkonzentration, die der Prothrombinkonzentration in der Ausgangsprobe entspricht.

\section{References}

(1) Hemker, H. C., A. D. Muller: Kinetic aspects of the interaction of blood-clotting enzymes. Thrombos. Diathes. haemorrh. (Stuttg.) 19: 368 (1968).

(2) Hemker, H.C., A. D. Muller, E.A. Loeliger: Two types of prothrombin in vitamin K deficiency. Thrombos. Diathes. haemorrh. (Stuttg.) 23: 3 (1970).

(3) Biggs, R., R. G. Macfarlane: Human blood coagulation and its disorders. Blac-well Scientific Publications, Oxford 1967.

(4) Wagner, R. H., J. B. Graham, G. D. Penick, K. M. Brinkhous: Estimation of prothrombin by the two-stage method. In: Blood Coagulation, Hemorrhage and Thrombosis. Edited by Dr. M. Leandro Tocantins and L. A. Kazal. 1965.

(5) Owren, P.A., K. Aas: The control of dicumarol therapy and the quantitative determination of prothrombin and proconvertin. Scand. J. clin. Lab. Invest. 3: 201 (1951).

(6) Loetiger, E. A., F. Koller: Behaviour of factor VII and prothrombin in late pregnancy and in the newborn. Acta haemat. (Basel) 8: 157 (1952).

(7) Hensen, A., E. A. Loeliger: Antithrombin III. Thrombos. Diathes. haemorrh. (Stuttg.) Suppl. 11 (1963).

(8) Hemker, H. C.: Unpublished results. 1969.

Received for Publication 4.1.1971

Copyright by F. K. Schattauer Verlag, Stuttgart - Der Verlag behält sich alle Rechte, besonders die des Nachdruckes, der Vervielfältigung und der Ubersetzung vor. 